\title{
The Civil-Military Integration and the Development of Education System in Defense Institutions: Indonesia's Case
}

\author{
Muradi $^{1}$ \\ ${ }^{1}$ Department of Government, Faculty of Social and Political Sciences, University of Padjadjaran, Jatinangor, \\ Indonesia \\ Correspondence: Muradi, Department of Government, Faculty of Social and Political Sciences, University of \\ Padjadjaran, Jl. Ir. Soekarno KM 21, Jatinangor, 45363 Indonesia. E-mail: muradi_clark@unpad.ac.id
}

Received: December 14, 2016

doi:10.5539/ass.v13n3p36

\author{
Accepted: January 14, 2017 Online Published: February 15, 2017 \\ URL: http://dx.doi.org/10.5539/ass.v13n3p36
}

\begin{abstract}
There are demands for defense educational institution to contribute in general knowledge, not only in the substance of war and defense science. It is also related to current threat against a country that is no longer just conventional, but also non-conventional threats that cover dynamics in civil society. This paper will discuss civil-military integration (CMI) in the development of education in military and defense institutions in Indonesia. It will also offer five levels of CMI in education. Each level has different CMI weights in education. In addition, this paper argues that CMI as part of Civil-Military Relations (CMR) provides a perspective that the development of education in military and defense institution can not simply adopt the general education system and pattern in civil institutions, but require the integration of mutually reinforcing and confirms the characteristics and patterns of education in professional military institution without losing the distinctiveness of education in the defense institution.
\end{abstract}

Keywords: Military, CMI, CMR, Defense Institution, Defense Education

\section{Introduction}

Defense educational institution in Indonesia is experiencing rapid development, marked by the founding of Indonesian Defense University (here after UNHAN) that focuses on Post-graduate Scientific Development (Master Program) and currently designing the doctoral program (Note 1). The presence of UNHAN with its post-graduate programs encourages other defense institutions, Army, Navy, Air Force and also Ministry of Defense to enroll their best personnel to study in UNHAN. This university under Ministry of Defense also accepts students from other institutions related to defense and security issues, in the scheme of a full scholarship (Note 2).

Difficulties in early formation of UNHAN is that no military officer is college graduates or at least have equivalent academic degree like civil students, as pre-requisites for post-graduate education. Many officers studying in UNHAN are civil-recruited officers (Draft) who have college degree, or officers who postpone his duties to take undergraduate courses. Initially the situation was resolved when there is no necessity for prospective military background students to hold a bachelor's college, as long as they are recommended by their unit and pass admissions test (Note 3). At the same time, Ministry of Defense, Armed Forces headquarters, and all armed forces units issued a policy that graduates of military academy have earned an academic educational degree, as part of an integrated education system. So that all graduated officers from the academy is able to continue the post graduate level in UNHAN and applied master degree by each dimension (Note 4).

However, the problem re-appears when graduated officer from the military academy do not have undergraduate education certificates and Master Degrees graduated of UNHAN are not accepted by other universities with Doctoral program. Although a number of universities finally received UNHAN graduates under certain conditions, but the situation is not solved, because not all UNHAN graduates are automatically accepted for higher education level (Note 5).

UNHAN experiences above shows that the management and development of education in the defense institution require important adjustment in mechanism at the national level. This adjustment does not have to eliminate education character in military institutions. The demand with officer's qualification is not only proficient in 
combat and non-combat military role, but also has academic qualifications with ability to read and understand the dynamics of society simultaneously (Note 6). Defense perspective is no longer limited to conventional warfare where non-traditional security threat requires different skills of military officers. Combined military training and national education system is expected to produce military officers with expected qualifications.

This paper will discuss civil-military integration (CMI) on the development of education in the military and defense institutions. It will also offer five levels of CMI in education field. Each level has different weights associated with CMI in education field. In addition, this paper argues that CMI as part of a Civil-Military Relations (CMR) provides a perspective that the development of education in the military and defense institution can not simply adopt the system and pattern of education applied in civilian institutions, but requires integration of mutually reinforcing and confirms the characteristics and patterns of education in professional military institution without losing the distinctiveness of education in the defense institution.

\section{Civil-Military Integration and Educational Institutions of Defense}

The Civil-Military Integration (CMI) term is widely used to describe the integration of technology and defense industry with civil technology and industry. Collaboration between the two later then defined by the Office of Technology Assessment of the US Congress, as the process of merging the Defense Technology and Industrial Base (DTIB) and the larger Commercial Technology and Industrial Base (CTIB) into a unified National Technology and Industrial Base (NTIB) (Note 7). However, in this paper, the civil-military integration is focused on the collaboration of civil and military perspective in the development of education system in the defense institutions rather than on the development and integration of technology and industry. Therefore, by adopting the definition associated with the integration of civilian-military in the development of education, it can be defined as follows: "The process of merging the military and defense educational system (SPMP) with the national civil educational system (SPSN) to make education system in the defense institution with fixed characteristics and patterns that exist but are connected to the national education system".

Conceptually, the CMI in the integration perspective of technology and defense industry and civilian industry and technology, there are three levels to describe the maturity and reliability of the technology and industrial integration between military and civilian. They are: management sector (Sector Level), the level of institutionalization of the firm (Firm Sector), and the third level of the facility (Facility Level).

At integration level of civil-military technology and industrial sectors, they are in the stages where they share common technology, processes, and special assets e.g. wind tunnels, technological research centers and industry. An integrated industrial sector can be said if the goods or services of defense drawn from a source of the same industry, specialized assets, and processes go hand in hand (Note 8).

While integration at the enterprise level is marked by sharing resources owned company to meet the needs of defense and commercial needs. These resources include management, employees, research centers, equipment, stock, and public facilities. A company that facilitates the movement of staff between defense and commercial work and the transfer of manufacturing and technology products back and forth can be considered to be integrated at the enterprise level, although it may separate operating divisions along the lines of commercial and defense (Note 9).

While the third level and the deepest level of integration is within the facility. Integration at this level is characterized by the division of personnel, equipment, and stock in a single facility. In an integrated facility, defense and commercial goods will be produced side by side, with differences in the production process and other parts that are dictated solely by the function of the product (Note 10).

In the context of civil-military integration on educational development, these stages can be adopted and developed into five stages (see Table 1), with more oriented on how to develop education in the defense institution. The thing that distinguishes the target and objective is civil-military integration in the development of educational institutions should be more independent in the educational pattern and characteristic.

Sector level stages in civil-military integration on the development of defense education in military institutions adopt a number of studies in order to strengthen the analysis of civil and military operations and defense interests. At this stage, approaches emphasize the importance of civil-military relations with various studies to strengthen civil-military interest in the role and function of professional soldiers (Note 11). At this level, educational defense institutions just take advantage of the teaching staff are considered capable of providing the required studies perspective.

In the second step, the interactions between civilians and the military in the educational field has emphasized the importance of civic studies for military operations and border control. In addition to establishing a study center 
or scientific research institutions, slowly and planned, military and defense institution then share educational curriculum to be studied on a limited basis to sustain the role and function of military and defense institutions. In a certain degree, the transition process in establishing University or higher education institution is oriented to strengthen civil assessment in order to strengthen the role and functions of defense institution gradually.

At the third level, civil-military integration is established with adjustment in facility and recognition of a degree generated by defense educational institutions. Some adjustments are made as plan to articulate stronger integration between civil and military education. Indication of the reinforcement is on the recognition of graduates from defense educational institutions in national education system. At this stage, in general, educational dichotomy between civil and military is no longer admitted by accepting civilian students in defense educational institutions.

The fourth stage of the civil-military integration is to strengthen education curriculum from their respective educational institutions and civil defense. One indicator in the level is the defense educational institution is able to meet the requirement of teaching staff independently, based on internal needs and good qualifications. Civilian role in this level is to ensure that the existing curriculum in the defense institution remains connected with the applicable national education system. This one is to emphasize the importance of quality of lecturers in their field of taught study.

The fifth stage, the highest stage of civil-military integration in the field of educational defense, is at the level of competence resulted from education of both institutions, civilian and military. Competence of civilian and military graduates showed that the defense educational institution is integrated in the national education system. Defense issues once considered is difficult to understand by civil society, in this stage, becomes an integral part. The shifting threat of traditional security threats into non-traditional security threats asserts defense should no longer simply be viewed from a limited perspective to the importance of civil-military integration in education. Defense education eventually will find their own character, but the relationship between civil-military will strengthen in other forms to ensure that the education quality is correlated with educational infrastructure and human resources remain linear with the national education system.

Table 1. Comparison of Civil-Military Integrity (CMI) Strategic Defense Industry and Educational Institutions

\begin{tabular}{|c|c|c|c|c|}
\hline \multirow[t]{2}{*}{ No. } & \multirow{2}{*}{\multicolumn{2}{|c|}{$\begin{array}{l}\text { Civil-Military Integration(CMI) } \\
\text { Strategic Industry (Note 12) }\end{array}$}} & \multirow{2}{*}{\multicolumn{2}{|c|}{$\begin{array}{c}\text { Civil-Military Integration (CMI) } \\
\text { Education (Note 13) }\end{array}$}} \\
\hline & & & & \\
\hline 1. & Sector Level & Technology Sharing & Sector Level & $\begin{array}{l}\text { Adopting civil researches for } \\
\text { defense needs }\end{array}$ \\
\hline 2. & $\begin{array}{l}\text { Corporate } \\
\text { Level }\end{array}$ & Resource Sharing & Corporate Level & $\begin{array}{l}\text { Adjustment and/or establish } \\
\text { education institution }\end{array}$ \\
\hline 3. & Facility Level & $\begin{array}{l}\text { Sharing of personnel, equipments, stocks } \\
\text { in a single facility }\end{array}$ & Facility Level & Adjustment of education institution \\
\hline 4. & - & & $\begin{array}{l}\text { Curriculum } \\
\text { Level }\end{array}$ & Independent curriculum \\
\hline 5. & - & & $\begin{array}{l}\text { Competency } \\
\text { Level }\end{array}$ & Equal competency \\
\hline
\end{tabular}

\section{Education Scheme Civil-Military Integration}

Each level in civil-military integration in defense education has prerequisites as described in the beginning. However, civil-military integration in defense education is often disrupted by deviant practices of cronyism eroding professionalism of the institutions. Experiences of some countries, in the end, showed poor intention and commitment when addressing the practice of cronyism and deviations in of defense and military educational institutions. The built commitment determines the real picture of the institution. Leaving deviant practices would only delay the development of defense educational institutions into professional. Indeed, there are steps to read and identify deviant practices so that the way to improve the desired institutional can be measured.

There are four deviant practices that could threat the development of defense educational institutions. The first, related to the Human Resources (HR) Quality of the lecturers. There are two variations of irregularities relating to this case, namely: the incompetence of the teaching staff and nonlinearities qualifications related to the subject taught.

Second, the interrupted curriculum development by desires of human resources, not based on the need of the education. So often the curriculum is made to accommodate the wish of the existing teaching force. No wonder 
if then the perspective that is built is not entirely based on the development of professional education institutions.

Third, the faculty intervention in selecting lecturers based on the plotted competence and qualifications. Intervention and interference to determine names of lecturers are usually associated with their approaches to the leader of the institution or being assigned to teach subjects that is not lecturer's qualifications.

Fourth, the dichotomy between academic soldier and field soldier. The perception in the end affected the focus of development of educational institution. Lecturers and leaders of this institution only used defense educational institutions as stepping stone to gain strategic and higher rank.

Reflecting on emphasis of Civil-Military Integration on education in the defense institution with five stages as stipulated above and practices that threaten deviations inside civil-military integration educational scheme, there are six items should be noted for civil-military integration education scheme to work well: First, characteristics of professional armed forces should not be lost. It should be underlined that the civil-military integration is needed in the field of education development so the military able to respond complex security threats. Therefore it is difficult to imagine if professional military characteristics in education institution is lost when the development of defense educational institution is success.

Second, scientific approaches taught in the institution must integrate the role and function of the military with the dynamics of social-community. It should be underlined that the desire of military institutions of to study various scientific fields is not to reactivate the Dual Function, but as part of a response to the growing traditional and non-traditional security threats. So, paradigmatic analysis is performed as respond to more comprehensive and thorough process to understand more on the existing problems.

Third, supporting roles and functions of the military, not the other way around. It is important to underline that the development of educational defense institutions with the civil integration scheme must strengthen the role and function of the military in a professional manner and not vice versa. Stimulation built by civilians is to improve the role and function of the military effectively so that the professionalism of the soldiers can be realized.

Fourth, the role of civil gradually will be reduced so that the capacity is just supporting, not primary. This emphasizes the need for the defense institution to take advantage of the existing human resources in order to approach the qualification and competency required in accordance with the national education system.

Fifth, capacity of the lecturer is a must, not only military career background. Discrepancies on the need of defense educational development became obstacles and problems that must be solved together. The assumption that educational institution is a burden for defense structures and only become shortcut to accommodate a number of human resources can not be accommodated within the existing organizational structure, should be gradually eliminated. Approaches of professionalism with qualification gradually adjusted to the national education system, should be applied to ensure the quality of graduates from defense education is equivalent to graduates from national education system.

Sixth, the Recruitment process of lecturers. There are three sources of recruitment for lecturers, the active officers, which will gradually choose to retire from service, retired officers with good experience and academic qualifications, and civilian who are parts of the integrated civil-military system. Active officer who wants to become lecturer with appropriate qualifications and competence will be asked to choose whether to focus on teaching or active as a military officer. This needs to be done gradually so that the characteristics of the scientific and educational process can be continuously carried out.

While the source of retired officers also needs to be underlined to refer to the competence and qualifications required for defense educational institutions. It should be considered that recruiting retired officers as reward for their long service in military institutions must gradually be reduced. Until the time conditioned a number of officers who wanted to continue his service to the educational institutions of defense, either through early retirement or after the retirement. As for purely civilian, educational institutions should also have professional lecturers appointed permanently to strengthen the competency and qualification of human resources according to the needs of national education system.

\section{Conclusion}

Civil-Military Integration (CMI) in the development of military and defense education requires a number of prerequisites created in the process to run synergistically with each other. Five levels of CMI in the field of education should be based at least on five issues: quality of human resources, infrastructure, education, curriculum, integrated national education system and political policy to establish defense educational institution. This paper also concludes that the CMI as part of a variant of Civil-Military Relations (CMR) provides a 
perspective that the development of education in the military and defense can not simply adopt the system and pattern education applied in civilian educational institutions, but requires integration to reinforce and confirm characteristics and patterns of education in professional military institution without losing the distinctiveness of defense education itself.

\section{References}

Anoymous. (1995). Assessing the Potential for Civil Military Integration: Selected Case Studes. Washington: OTA-Congress of the United States.

Department of Defense. (1991). Projected Defense Purchases Detailed by Industry and State: Calendar years 1991 to 1997. Washington DC: Department of Defense.

Finer, S. E. (1962). The Man on Horse Back: The Role of the Military in politics. New York: Praeger.

Huntington, S. (1957). The Soldier and the State. Cambridge: Harvard University.

Korski, D. (2009). British Civil-Military Integration: the History and Next Steps. The RUSI Journal, 154(6).

Office of Technology Assessment-Congress of the United States. (March, 1995). Other Approaches to Civil-Military Integration: The Chinese and Japanese Arms Industries. Washington: OTA-Congress of the United States.

Samuels, J. (1994). Rich Nation, Strong Army. New York: Cornell University Press.

Tagarev, T. D. (1997). The Role of Military Education in Harmonizing Civil- Military Relations (the Bulgarian Case). Sofia: NATO Democratic Institutions Fellowship Programme.

U.S. Congress, Office of Technology Assessment, Adjusting to a New Security Environment: The Defense Technology and Industrial Base Challenge, OTA-BP-ISC-79 (Washington, DC: U.S. Government Printing Office, February 1991.

Vincent, R. Lindenmeye, R., \& Ulrich, M. P. (May, 2010). Integrating Civil-Military Relations into the Professional Military Education Curriculum within the Republic of Moldova's Military Institute. US Army College: Center for Strategic Leadership.

\section{Notes}

Note 1. See Inilah.com (2016). "Menhan Bahas Universitas Pertahanan". http://nasional.inilah.com/read/detail/28028/menhan-bahas-universitas-pertahanan (accessed 11 August 2016).

Note 2. See Okezone.com. (2016). "Mau Bela Negara, Ikut Beasiswa Unhan". http://news.okezone.com/read/2013/05/29/373/814672/mau-bela-negara-ikut-beasiswa-di-s2-unhan-saja (accessed 11 August 2016).

Note 3. See, Republika. (2015). "Unhan Wisuda 41 Magister Pertahanan". "http://www.republika.co.id/berita/pendidikan/dunia-kampus/13/02/20/miilgs-unhan-wisuda-41-magister-pertaha nan (accessed 11 September 2016).

Note 4. Republika. (2015). "Unhan Wisuda 41 Magister Pertahanan". "http:/www.republika.co.id/berita/pendidikan/dunia-kampus/13/02/20/miilgs-unhan-wisuda-41-magister-pertaha nan (accessed 11 September 2016).

Note 5. A university encouraging graduates of National Defense University (UNHAN) to enclose undergraduate certificate and score sheet is Universitas Indonesia (UI). Other universities may have different policy by accepting post-graduates from UNHAN to continue their doctoral program. Some of them are University of Padjadjaran (UNPAD), Bandung, State Universiy of Jakarta (UNJ), and University of Gajah Mada, Yogyakarta (UGM).

Note 6. See Pikiran Rakyat.Com. (2015). "Unhan Hasilkan 45 Master Pertahanan". http://www.pikiran-rakyat.com/pendidikan/2012/05/16/188694/unhan-hasilkan-54-master-pertahanan (accese 11 september 2016).

Note 7. More on U.S. Congress, Office of Technology Assessment, Adjusting to a New Security Environment: The Defense Technology and Industrial Base Challenge, OTA-BP-ISC-79 (Washington, DC: U.S. Government Printing Office, February 1991.

Note 8. US Congress. Ibid. p. 5. 
Note 9. US Congress. Ibid. p. 6.

Note 10. US Congress. Ibid. pp. 7-8.

Note 11. Some related sources on classical perspective in civil-military relation, see. Huntington, Samuel. (1957). The Soldier and the State. Cambridge: Harvard University. Especially chapter 1. Finer, Samuel E. (1962). The Man on Horse Back: The Role of the Military in politics. New York: Praeger. See chapter 3.

Note 12. Office of Technology Assessment-Congress of the United States. (Sept. 1995). Assessing the Potential for Civil Military Integration: Selected Case Studies. Washington DC: OTA-Congress of the United States. pp. $1-5$.

Note 13. Inspired by CMI in strategic industries, then summarized and translated personally by author. The meaning and content is fully author's responsibility.

\section{Copyrights}

Copyright for this article is retained by the author(s), with first publication rights granted to the journal.

This is an open-access article distributed under the terms and conditions of the Creative Commons Attribution license (http://creativecommons.org/licenses/by/4.0/). 